\title{
Modeling sound pulse counting in inferior colliculus
}

\author{
Richard Naud ${ }^{1 *}$, Dave Houtman ${ }^{1}$, Gary J Rose ${ }^{2}$, André Longtin ${ }^{1}$ \\ From The Twenty Third Annual Computational Neuroscience Meeting: CNS*2014 \\ Québec City, Canada. 26-31 July 2014
}

The ability of animals to count events or objects and its underlying mechanisms - including the possible existence of a dedicated "number sense" - is a topic of much recent fascination and research interest. A simple computation that frogs execute routinely is counting the number of consecutive sound pulses in a conspecific call that occur with precise and regular timing [1]. Cells signaling that a threshold number of pulses have occurred have been found in the midbrain of anurans [2]. These counting cells will not respond if a single inter-pulse interval is a few milliseconds longer than the baseline interval. What intrinsic or network mechanisms can give rise to such pulse/interval counting? Comparing simplified neuron models with previously published in vivo membrane potential recordings [3], we identify biophysical processes that can explain the observations. First, we consider a

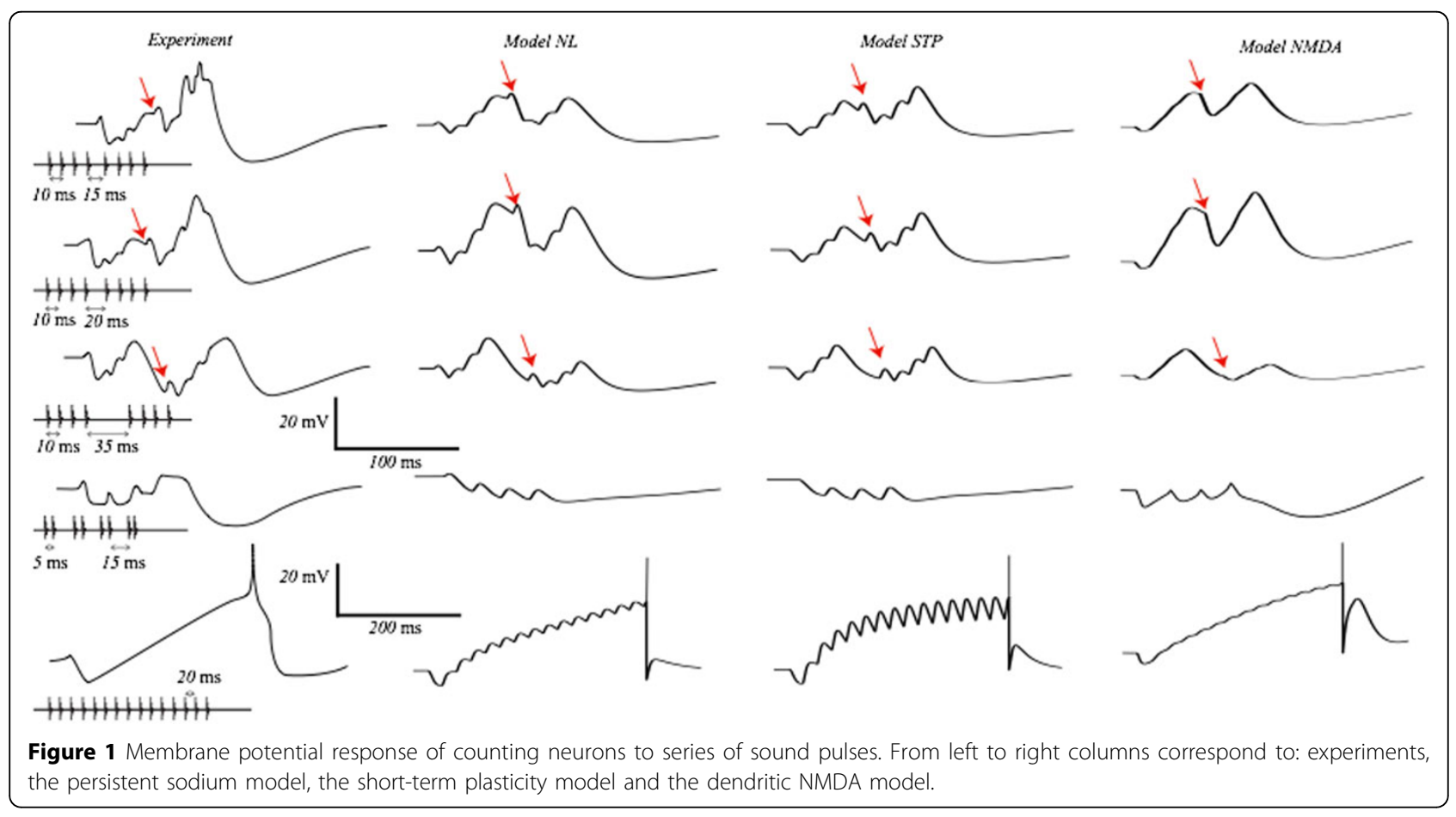

* Correspondence: rnaud@uottawa.ca

'Department Physics, University of Ottawa, Ottawa, K1N 6N5, Canada

Full list of author information is available at the end of the article

\section{() Biomed Central}

(c) 2014 Naud et al; licensee BioMed Central Ltd. This is an Open Access article distributed under the terms of the Creative Commons Attribution License (http://creativecommons.org/licenses/by/4.0), which permits unrestricted use, distribution, and reproduction in any medium, provided the original work is properly cited. The Creative Commons Public Domain Dedication waiver (http:// creativecommons.org/publicdomain/zero/1.0/) applies to the data made available in this article, unless otherwise stated. 
model of phasic inhibition made of onset and offset inhibition. Phasic inhibition enhances reset because a longer interval will engender onset and possibly offset inhibition. Second, we consider four mechanisms, namely short-term facilitation of excitation, persistent sodium currents, dendritic NMDA synapses and recurrent connections of cells imbedded in a network. Combining phasic inhibition with either of these mechanisms can qualitatively reproduce the array of recordings for different pulse patterns - including those with pauses that reset the counting - as well as the effect of pharmacologically attenuating inhibition. These results support the hypothesis that prior segmentation of sound via phasic on and off responses underlies the emergence of features such as pulse counting and duration selectivity in the auditory midbrain.

Authors' details

'Department Physics, University of Ottawa, Ottawa, K1N 6N5, Canada.

${ }^{2}$ Department Biology, University of Utah, Salt Lake City, UT, 84112, USA.

Published: 21 July 2014

\section{References}

1. Klump GM, Gerhardt HC: Use of non-arbitrary acoustic criteria in mate choice by female gray tree frogs. Nature 1987, 326:286-288.

2. Edwards CJ, Alder TB, Rose GJ: Auditory midbrain neurons that count. Nat Neurosci 2002, 5(10):934-936.

3. Edwards CJ, Leary CJ, Rose GJ: Counting on inhibition and ratedependent excitation in the auditory system. J Neurosci 2007, 27(49): 13384-13392.

doi:10.1186/1471-2202-15-S1-P113

Cite this article as: Naud et al.: Modeling sound pulse counting in inferior colliculus. BMC Neuroscience 2014 15(Suppl 1):P113.
Submit your next manuscript to BioMed Central and take full advantage of:

- Convenient online submission

- Thorough peer review

- No space constraints or color figure charges

- Immediate publication on acceptance

- Inclusion in PubMed, CAS, Scopus and Google Scholar

- Research which is freely available for redistribution

Submit your manuscript at www.biomedcentral.com/submit 